\title{
Intrinsic Resistance of Oligodendrocytes to Prion Infection
}

\author{
Marco Prinz, ${ }^{1 \star}$ Fabio Montrasio, ${ }^{1 \star}$ Hisako Furukawa, ${ }^{1}$ Marjan E. van der Haar, ${ }^{2}$ Petra Schwarz, ${ }^{1}$ Thomas Rülicke, ${ }^{3}$ \\ Olivier T. Giger, ${ }^{1}$ Karl-Georg Häusler, ${ }^{1}$ Daniel Perez, ${ }^{1}$ Markus Glatzel, ${ }^{1}$ and Adriano Aguzzi ${ }^{1}$ \\ ${ }^{1}$ Institute of Neuropathology, University Hospital of Zürich, CH-8091 Zürich, Switzerland, ${ }^{2 B}$ rain Research Institute, Department of Neuromorphology, \\ University of Zürich, CH-8057 Zürich, Switzerland, and 'Institute of Laboratory Animal Science, University of Zürich, CH-8091 Zürich, Switzerland
}

Within the CNS, the normal form of cellular prion protein $\left(\operatorname{PrP}^{C}\right)$ is expressed on neurons, oligodendrocytes, and astrocytes. The contribution of these cell types to prion replication and pathogenesis is unclear. To assess the role of oligodendrocytes, we expressed $\operatorname{PrP}^{\mathrm{C}}$ under the control of the myelin basic protein (MBP) promoter in mice lacking endogenous $\operatorname{PrP}^{\mathrm{C}} \cdot \operatorname{PrP}^{\mathrm{C}}$ was detected in oligodendrocytes and Schwann cells but not in neurons and astrocytes. MBP-PrP mice never developed scrapie after intracerebral, intraperitoneal, or intraocular challenge with scrapie prions. Transgenic brains did not contain protease-resistant prion protein and did not transmit scrapie when inoculated into $\mathrm{PrP}^{\mathrm{C}}$-overexpressing indicator mice. To investigate whether prion spread within the CNS depends on oligodendrocytic $\mathrm{PrP}^{\mathrm{C}}$, we implanted $\mathrm{PrP}^{\mathrm{C}}$-overexpressing neuroectodermal grafts into MBP-PrP brains. After intraocular prion inoculation, none of the grafts showed spongiform encephalopathy or prion infectivity. Hence oligodendrocytes do not support cellautonomous prion replication, establishment of subclinical disease, and neural spread of prions. Prion resistance sets oligodendrocytes aside from both neurons and astrocytes.

Key words: prion; $\mathrm{PrP}^{\mathrm{Sc}}$; oligodendrocytes; myelin basic protein; transgenic mice; scrapie

\section{Introduction}

Prion protein $(\mathrm{PrP})$ plays a central role in the pathogenesis of transmissible spongiform encephalopathies (TSEs) such as sheep scrapie, bovine spongiform encephalopathy, and CreutzfeldtJakob disease (Aguzzi and Weissmann, 1997; Aguzzi et al., 2001). The normal form of $\operatorname{PrP}$, designated $\operatorname{PrP}^{\mathrm{C}}$, is encoded by the Prnp gene (Basler et al., 1986), and is almost ubiquitously expressed. In the $\mathrm{CNS}, \operatorname{PrP}^{\mathrm{C}}$ is predominantly neuronal, but expression on astrocytes and oligodendrocytes is also detectable (Moser et al., 1995). Prnp ${ }^{\mathrm{o} / \mathrm{o}}$ mice are devoid of $\operatorname{PrP}^{\mathrm{C}}$ and develop and behave normally (Büeler et al., 1992) but are resistant to prion disease (Büeler et al., 1993) and do not support replication of prions (Sailer et al., 1994). Reintroduction of PrP transgenes into $P r n p^{\mathrm{o} / \mathrm{o}}$ mice, even when carrying significant amino-proximal deletions, restores susceptibility to scrapie (Fischer et al., 1996; Shmerling et al., 1998; Flechsig et al., 2000).

\footnotetext{
Received Jan. 13, 2004; revised April 21, 2004; accepted May 14, 2004.

This work was supported by grants from the Swiss National Research Fund, the National Center of Competence in Research, Neuronal Plasticity and Repair, and the European Union (Bundesamt für Bildung und Wissenschaft) (A.A.) M.P. was a postdoctoral fellow of the Deutsche Forschungsgemeinschaft (Grant Pr 577/2-1). We thank Jürgen Roth, Marius Lötscher, and Maria Grazia Barenco for their help. We also thank Dr. M. Kimura (Tokai University, Isehara, Japan) for providing the pMP302 vector.

*M.P. and F.M. contributed equally to this work

Correspondence should be addressed to Dr. Adriano Aguzzi, Institute of Neuropathology, University Hospital of Zürich, Schmelzbergstrasse 12, CH-8091 Zürich, Switzerland. E-mail: adriano@pathol.unizh.ch.

M. Prinz's present address: Institute of Neuropathology, Georg-August-University Göttingen, Robert-KochStrasse 40, D-37075 Göttingen, Germany.

F. Montrasio's present address: Prion Research Group, Paul-Ehrlich-Institute, Paul-Ehrlich-Strasse 51-59, D-63225 Langen, Germany.

H. Furukawa's present address: Department of Pharmacology 1, Nagasaki University Graduate School of Biomedical Sciences, 1-12-4 Sakamoto, 852-8523 Nagasaki, Japan.

M. E. van der Haar's present address: Prionics AG, Wagistrasse 27a, CH-8952 Schlieren, Switzerland. D01:10.1523/JNEUROSCI.0122-04.2004

Copyright $\odot 2004$ Society for Neuroscience $\quad 0270-6474 / 04 / 245974-08 \$ 15.00 / 0$
}

Previous transgenetic studies have revealed that expression of $\operatorname{PrP}^{\mathrm{C}}$ on either neurons or astrocytes is sufficient for scrapie replication (Race et al., 1995; Raeber et al., 1997). Surprisingly, mice expressing $\mathrm{PrP}^{\mathrm{C}}$ only within astrocytes or only within neurons develop indistinguishable pathologies after prion infection. Although oligodendrocytes express $\operatorname{PrP}^{\mathrm{C}}$ and are histogenetically highly related to astrocytes, it is not known whether they play a role in prion replication and in development of brain damage. White-matter involvement in TSEs was proposed to be a result of direct modifications of oligodendrocyte physiology (El Hachimi et al., 1998). If this is the case, oligodendrocytes may contribute to the pathogenetic process of scrapie.

The mechanisms by which prions spread within the CNS are unknown. Although neuronal trans-synaptic spread appears plausible, expression of $\mathrm{PrP}^{\mathrm{C}}$ in myelinating cells and the alleged potential of cultured Schwann cell lines to generate prion infectivity during infection (Follet et al., 2002; Archer et al., 2004) raise a possible role for oligodendrocyte-borne $\mathrm{PrP}^{\mathrm{C}}$ in the cerebral spread of prions. The latter issue may be of practical interest, because neuroinvasion can occur, for example, via the heavily myelinated visual pathway after conjunctival instillation (Scott et al., 1993), corneal grafts (Duffy et al., 1974), and intraocular injection (Fraser, 1982).

These questions would be testable in animals that express $\operatorname{PrP}^{\mathrm{C}}$ exclusively on myelinating cells. Expression would have to be sustained and highly selective, with no other cells expressing $\operatorname{PrP}^{\mathrm{C}}$. Here we describe transgenic mice expressing $\operatorname{PrP}^{\mathrm{C}}$ under the control of the myelin basic protein (MBP) promoter. $\mathrm{PrP}^{\mathrm{C}}$ was strongly and exclusively expressed in oligodendrocytes and Schwann cells, but not in neurons or astrocytes. Using this model, we have established that expression of $\operatorname{PrP}^{\mathrm{C}}$ on myelinating cells does not support prion replication or spread of the agent along 
neural pathways. These results are in contrast to previous evidence that had been gathered with cultured cells and negate any cell-autonomous role for myelinating cell-borne $\operatorname{PrP}^{\mathrm{C}}$ in the pathogenesis of prion diseases.

\section{Materials and Methods}

DNA constructions and generation and identification of transgenic mice. A blunt-ended $760 \mathrm{bp}$ fragment containing the entire $\operatorname{PrP}$ open reading frame (ORF) region (corresponding to exon 3 of the Prnp gene) (Fischer et al., 1996) was introduced and ligated into the EcoRI restriction sites of the MBP construct (see Fig. $1 A$ ). The $1.3 \mathrm{~kb}$ promoter region of the mouse MBP gene contains the cap site of MBP mRNA and 5' noncoding sequences. Although the cDNA fragment used is only approximately two-thirds as long as the normal MBP cDNA and does not contain sequences corresponding to the $3^{\prime}$ portion of MBP mRNA, it contains the full coding sequence of $14 \mathrm{kDa}$ for the smallest mouse MBP. Poly(A) addition signals are provided from rabbit $\beta$-globin and simian virus 40 early genes, and the second intron of the rabbit $\beta$-globin gene is placed between the cap site and PrP ORF for splicing.

Plasmid DNA was digested with HindIII and SalI and microinjected into homozygous $\operatorname{Prnp}^{\mathrm{o} / \mathrm{o}}$ zygotes, as described previously (Fischer et al., 1996). Using PCR, founders were identified by the presence of Prnp ${ }^{\circ}$ alleles and Prnp ${ }^{+}$transgenes. The primers P3 (specific for the disrupted Prnp allele), P10 (for the wild-type Prnp gene), and Mut217 (exon 3 primer) were used under standard PCR conditions (Fischer et al., 1996). Transgenic founders were mated to $\operatorname{Prn} \mathrm{p}^{\mathrm{o} / \mathrm{o}}$ mice, and one transgenic line, designated $\operatorname{tg} 640^{+/ \mathrm{o}}$, was established from the $\mathrm{F}_{1}$ progeny on a $\operatorname{Prnp}^{\mathrm{o} / \mathrm{o}}$ mixed background, C57BL/6 $\times 129 \mathrm{~Sv}$. Additional breeding yielded the homozygous line $\operatorname{tg} 640^{+/+}$, or MBP-PrP.

Northern blot analyses. Mouse-brain total RNA was isolated with RNAeasy Midi kits (Qiagen, Hilden, Germany), and samples (15 $\mu \mathrm{g})$ were electrophoresed through a $1 \%$ agarose gel in $0.02 \mathrm{M}$ sodium borate, $\mathrm{pH}$ 8.3, 0.5 mm EDTA, and 5\% formaldehyde. RNA was blotted onto Hybond- $\mathrm{N}^{+}$membranes (DuPont, Billerica, MA) using 20× SSC and cross-linked to membranes by ultraviolet radiation. Prehybridization occurred for $4 \mathrm{hr}$ at $42^{\circ} \mathrm{C}$ in $50 \%$ formamide, $1 \mathrm{M} \mathrm{NaCl}, 1 \%$ SDS, and $10 \%$ dextran sulfate. Hybridization occurred overnight at $42^{\circ} \mathrm{C}$ in the same buffer using ${ }^{32} \mathrm{P}$-labeled probe A $\left(10^{6} \mathrm{cpm} / \mathrm{ml}\right)$, prepared by random priming, which is known to hybridize to transcripts produced by both wild-type and disrupted Prnp genes (Büeler et al., 1992), and $0.1 \mathrm{mg} / \mathrm{ml}$ denatured salmon-sperm DNA. Membranes were washed for $10 \mathrm{~min}$ at room temperature (RT) in $2 \times \mathrm{SSC}$, washed twice for $30 \mathrm{~min}$ at $60^{\circ} \mathrm{C}$ in $2 \times$ SSC and $1 \%$ SDS, and washed twice for $30 \mathrm{~min}$ at RT in $1 \times$ SSC. Autoradiography was performed for 7-24 hr at RT using Eastman Kodak (Rochester, NY) XAR-5 film and an intensifier screen.

Western blot analysis. Brain homogenates were adjusted to $5 \mathrm{mg} / \mathrm{ml}$, and $50 \mu \mathrm{g}$ of total protein from each sample was electrophoresed through a $12 \%$ SDS-PAGE gel. Proteins were transferred to nitrocellulose by semidry blotting. Membranes were blocked with TBS-Tween 20 and 5\% nonfat milk, incubated with antibody 6H4 or POM1 (monoclonal antibody to PrP; M. Polymenidou and A. Aguzzi, unpublished data), and developed by enhanced chemiluminescence (Amersham Biosciences, Braunschweig, Germany), as described recently (Prinz et al., 2002). Quantification was performed using NIH Image software (http://rsb.info.nih.gov/nih-image/).

In situ hybridization. A $290 \mathrm{bp}$ Asp718-BstEII fragment of the mouse PrP cDNA was cloned into pBluescript KS and SK vectors (Stratagene, La Jolla, CA). Digoxygenin-labeled sense and antisense probes were synthesized (Boehringer Mannheim, Mannheim, Germany) from Asp718cleaved KS and SK constructs, respectively, using T3 RNA polymerase (Raeber et al., 1997). Sections were deparaffinized and postfixed in $4 \%$ paraformaldehyde in PBS, RNA was denatured for $10 \mathrm{~min}$ in $0.1 \mathrm{M} \mathrm{HCl}$, and sections were digested with $10 \mu \mathrm{g} / \mathrm{ml}$ proteinase $\mathrm{K}(\mathrm{PK})$ at $37^{\circ} \mathrm{C}$ for $10 \mathrm{~min}$. After a second fixation step in $4 \%$ paraformaldehyde for $10 \mathrm{~min}$, acetylation was performed in $0.1 \mathrm{~m}$ triethanolamine and $0.25 \%$ acetic anhydride, and prehybridization was performed in $5 \times$ SSC, $50 \%$ formamide, $5 \times$ Denhardt's solution, and $50 \mu \mathrm{g} / \mathrm{ml}$ yeast tRNA for $90 \mathrm{~min}$ at room temperature. Hybridization was performed in the same mixture, containing the digoxygenin-labeled probe $\left(50 \mathrm{ng} / \mathrm{ml} ; 12 \mathrm{hr} ; 58^{\circ} \mathrm{C}\right)$. Sam- ples were washed for $1 \mathrm{hr}$ at $65^{\circ} \mathrm{C}$ in 0.2 and $0.1 \times$ SSC, respectively, labeled with anti-digoxigenin Fab fragments (1:5000), and developed with 5-bromo-4-chloro-3-indolyl phosphate and 4-nitroblue tetrazolium chloride. Sections were mounted in glycerol gelatin.

Transmission electron microscopy. White matter was freshly prepared from mouse brains and fixed for $4 \mathrm{hr}$ at $4^{\circ} \mathrm{C}$ in PBS containing $4 \%$ formaldehyde and $0.1 \%$ glutaraldehyde. These small tissue fragments were immersed in $2 \mathrm{M}$ sucrose containing $15 \%$ polyvinyl pyrrolidone ( 10 $\mathrm{kDa}$; Sigma, St. Louis, MO), mounted on aluminum pins, frozen, and stored in liquid nitrogen. Grids with ultrathin sections [prepared according to Tokuyasu (1976)] were conditioned with PBS containing $0.5 \%$ milk powder and $0.02 \%$ Tween 20 for $10 \mathrm{~min}$, incubated with PrPspecific mouse IgG ( $10 \mu \mathrm{g} / \mathrm{ml}$ in conditioning buffer; clone 6H4; Prionics AG, Schlieren, Switzerland) for $2 \mathrm{hr}$ at room temperature, rinsed with $\mathrm{PBS}$, and incubated with $8 \mathrm{~nm}$ gold-labeled goat anti-mouse IgG (diluted to an absorbance of 0.1 at $525 \mathrm{~nm}$ with conditioning buffer) for $1 \mathrm{hr}$. After rinses with PBS and distilled water, grids were embedded and stained with methylcellulose and uranyl acetate. Micrographs were taken on a Zeiss (Oberkochen, Germany) EM 910 at an original magnification of $20,000 \times$.

Preparation of oligodendrocytes and immunofluorescence. Optic nerve oligodendrocytes were isolated from postnatal day 7-8 wild-type, transgenic, and $\operatorname{Prnp}^{\mathrm{o} / \mathrm{o}}$ mice, as described previously for the rat (Schwab and Caroni, 1988). Four days after isolation, cells were fixed with $4 \%$ paraformaldehyde and 5\% sucrose in PBS for $15 \mathrm{~min}$ at RT. The cultures were permeabilized and blocked in PBS supplemented with $0.1 \%$ Triton X-100 and 10\% FCS and then incubated with anti-myelin-associated glycoprotein (MAG; 1:100; Roche Diagnostics, Rotkreuz, Switzerland) and anti-PrP rabbit antiserum XN (1:800; raised against full-length murine $\mathrm{PrP}$ ) for $1 \mathrm{hr}$ at RT. After washing, the cells were incubated with goat anti-mouse secondary antibodies conjugated with Alexa 488 (1:150; Molecular Probes, Eugene, OR) and goat anti-rabbit Alexa 546 (1:500). After additional washing, stained cultures were embedded in Mowiol (Calbiochem, La Jolla, CA) and mounted on slides for fluorescence microscopy.

Scrapie infection and determination of infectivity. Mice were inoculated intraperitoneally with $100 \mu$ l of brain homogenate containing $6 \log \mathrm{LD}_{50}$, intracerebrally with $30 \mu \mathrm{l}\left(3 \times 10^{5} \mathrm{LD}_{50}\right)$ of the Rocky Mountain Laboratory (RML) scrapie strain (passage 5), or intraocularly with $10 \mu \mathrm{l}(1 \times$ $10^{5} \mathrm{LD}_{50}$ ) of the same RML scrapie strain, prepared as described previously (Büeler et al., 1993). Mice were monitored every second day, and scrapie was diagnosed according to standard clinical criteria. Mice were killed on the day of onset of terminal clinical signs of scrapie. Infectivity of tissues was determined on $1 \%$ spleen or brain homogenates. Tissues were homogenized $(10 \% \mathrm{w} / \mathrm{v})$ in $320 \mathrm{~mm}$ sucrose with a microhomogenizer, passed several times through 18 and 22 gauge needles, and diluted in PBS with 5\% BSA. When the solution appeared homogenous, it was spun for $5 \mathrm{~min}$ at $500 \times \mathrm{g}$. Supernatants $(30 \mu \mathrm{l})$ were inoculated intracerebrally into groups of four tga20 mice (Fischer et al., 1996). Indicator mice were killed after development of terminal scrapie and the relationship $y=11.45-0.088 x$, where $y$ is $\log \mathrm{LD}_{50} / \mathrm{ml}$ homogenate and $x$ is incubation time in days to terminal disease, was used to calculate infectivity titers (Prusiner et al., 1982). The presence of a protease-resistant isoform of $\operatorname{PrP}\left(\mathrm{PrP}^{\mathrm{Sc}}\right)$ in the infected brains was investigated on proteinase K-treated $\left(50 \mu \mathrm{g} / \mathrm{ml} ; 30 \mathrm{~min} ; 37^{\circ} \mathrm{C}\right)$ homogenates by Western blot analysis, as described above.

Histoblots. Histoblots were performed as described previously (Prusiner et al., 1982). Frozen brains that were cut into $12-\mu \mathrm{m}$-thick slices were mounted on nitrocellulose membranes. Total PrP, as well as $\mathrm{PrP}^{\mathrm{Sc}}$ after digestion with $50 \mu \mathrm{g} / \mathrm{ml}$ proteinase $\mathrm{K}$ for $4 \mathrm{hr}$ at $37^{\circ} \mathrm{C}$, were detected with PrP antibody 6H4 (1:2000 in 1\% nonfat milk, overnight at $4^{\circ} \mathrm{C}$ ) and alkaline phosphatase immunoconjugates. Visualization was performed using 5-bromo-4-chloro-3-indolyl phosphate and 4-nitroblue tetrazolium chloride (Boehringer Mannheim).

Establishment and analysis of intracerebral neuronal grafts. Embryos were obtained at day 12.5 after conception from homozygous matings of tga20 transgenic mice and transferred into modified HBSS that was supplemented with $10 \% \mathrm{FCS}$ and $2 \%$ glucose at $4^{\circ} \mathrm{C}$. The neuroectodermal anlage was prepared, homogenized in a volume of $30 \mu \mathrm{l}$, and grafted into the caudoputamen of adult wild-type mice, as described previously 

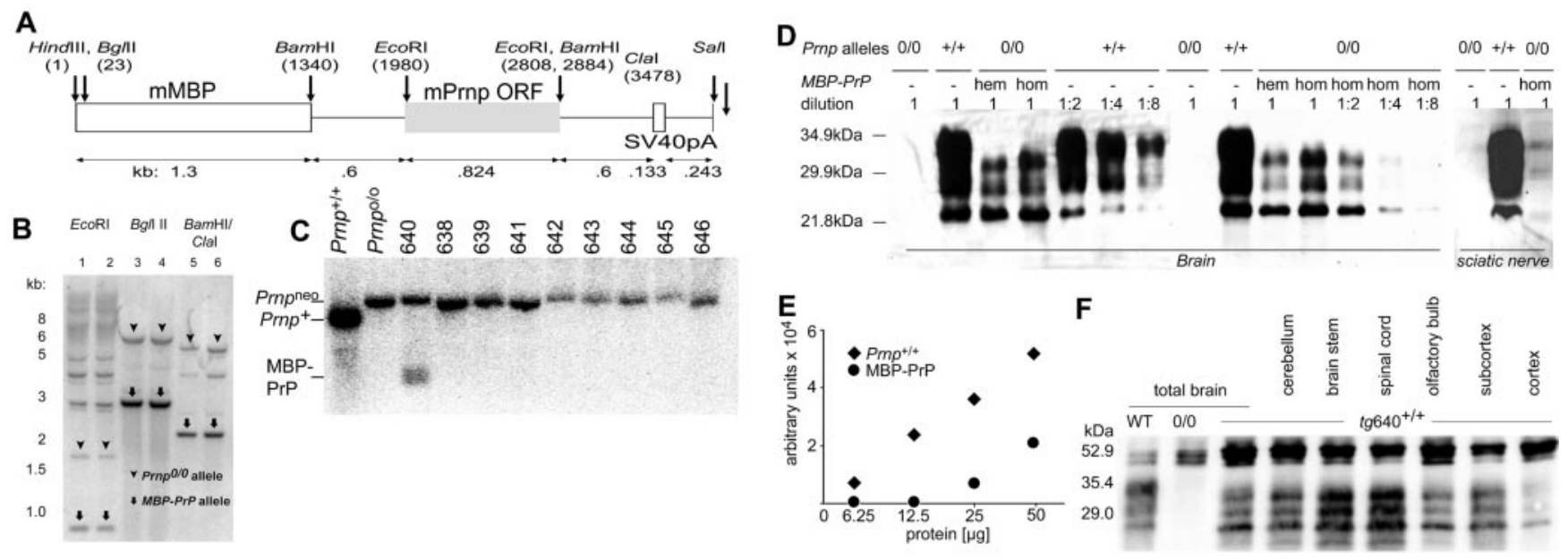

Figure 1. Generation and identification of MBP-PrP transgenic mice.A, Schematic drawing of the MBP-PrP transgene used for generation of transgenic mice. Arrows and parenthetical numbers indicate the respective restriction sites. The second intron of rabbit $\beta$-globin was placed between the cap site and MBP CDNA to improve transgene expression. mMBP, Mouse MBP; $m$ Prnp, mouse Prnp; SV40, simian virus 40. B, Genomic Southern blot analysis of MBP-PrP transgenic mice. EcoRl exactly excises the PrP ORF, confirming the presence of the transgene. (All tested mice showed the same banding pattern.) The Bg/ll and the BamHI-Clal digestions verify the integrity of the $5^{\prime}$ and $3^{\prime}$ ends, respectively. C, Northern blot analysis of brain RNA. The numbers above each lane indicate the various transgenic lines analyzed. RNA from wild-type $\left(P_{r n p}{ }^{+/+}\right.$) and Prnp ${ }^{0 / 0}$ brains was used as a control. D, PrP ${ }^{C}$ expression in brains and sciatic nerves of hemizygous (hem) or homozygous (hom) tg640 transgenic mice. Expression levels were estimated by comparison with serial twofold dilutions of wild-type brain homogenate. E, Brain $\operatorname{PrP}^{C}$ quantification by chemiluminescence analysis. The abscissa displays the amount of protein in micrograms; the ordinate shows chemiluminescence intensity (arbitrary units). F, Anatomical dissection of the CNS in the cerebellum, brainstem, spinal cord, olfactory bulb, and gray or white matter (cortex, subcortex) revealed strongest expression of $\operatorname{PrP}^{C}$ in white-matter or white-matter-rich regions of the CNS. MBP-PrP mice display a dominant unglycosylated $\operatorname{PrP}^{C}$ band, whereas wild-type mice show a dominant diglycosylated band. To facilitate sample comparisons, only $25 \%$ of total protein was loaded in wild-type samples, resulting in PrPC bands of similar intensity. The uppermost bands represent actin. WT, Wild type.

(Brandner et al., 1996a; Isenmann et al., 1996a,b). For histological analysis, mice were killed while under deep anesthesia. For paraffin histology, whole mouse brains were fixed for at least $72 \mathrm{hr}$ in $4 \%$ paraformaldehyde and PBS and processed for paraffin embedding. Hematoxylin and eosin staining and immunohistochemistry for GFAP (anti-GFAP antiserum; 1:300; Dako, High Wycombe, UK) and synaptophysin (synaptophysin antiserum; 1:40; Dako) were all performed on sections of paraffinembedded tissues. Biotinylated secondary antibodies (goat anti-rabbit and rabbit-anti mouse; Dako) were used at a 1:200-1:300 dilution. Visualization was achieved using biotin-avidin-peroxidase (Dako) and diaminobenzidine as a chromogen, according to the protocols suggested by the manufacturer.

\section{Results \\ MBP-PrP transgenic mice express $\operatorname{PrP}^{\mathrm{C}}$ exclusively on myelinating cells}

To drive expression of $\operatorname{PrP}^{C}$ in myelinating cells, we prepared a DNA construct in which the entire coding region of the murine Prnp gene was placed under the transcriptional control of a murine MBP promoter fragment. A similar strategy has been used for expressing myelin basic protein antisense transcripts to produce a shiverer-like hypomyelinating mouse model (Katsuki et al., 1988). The construct, consisting of the $1.3 \mathrm{~kb}$ promoter region of the mouse MBP gene and two $0.6 \mathrm{~kb}$ rabbit $\beta$-globin introns that flank the $0.76 \mathrm{~kb} \operatorname{PrP}$ open reading frame region (Fig. $1 A$ ), was excised from its prokaryotic backbone and injected into the pronuclei of $P r n{ }^{o / o}$ zygotes.

Transgenic founders were identified by PCR analysis and Southern blotting (Fig. $1 B$ ). Nine of 11 PCR-positive founder $\left(\mathrm{F}_{0}\right)$ mice transmitted the transgene to their offspring. Transgene-carrying animals were bred to $\mathrm{Prnp}^{\mathrm{o} / \mathrm{o}}$ mice. Transgene expression in the resulting mouse colony (mixed C57BL/ $6 \times 129 \mathrm{~Sv}$ ) was analyzed in organs of 12 -week-old $\mathrm{F}_{1}$ offspring. Unless otherwise specified, all subsequent analyses were performed with homozygous offspring of one line (designated $\operatorname{tg} 640$ ) that showed sustained transcription of the transgene (Fig.
1C). Northern blot analysis failed to detect expression of the transgene in spleen, kidney, thymus, liver, testes, lung, heart, and muscle (data not shown).

We amplified and sequenced genomic DNA of six randomly chosen mice, as well as RNA from brain samples of four randomly chosen mice, after retrotranscription, with primers encompassing the Prnp open reading frame, which is contained in one single exon. We only detected sequences corresponding to the wild-type Prnp open reading frame, thereby excluding mutations in the transgene or RNA editing leading to a mutated protein (data not shown).

We then assessed expression of $\operatorname{PrP}^{\mathrm{C}}$ by Western blot analysis. Homogenates of whole tg640 brains, as well as of subregions thereof, yielded a characteristic three-band pattern of unglycosylated, monoglycosylated, and diglycosylated $\operatorname{PrP}$ (Fig. 1D,F). Western blots of spleen, heart, lung, thymus, muscle, liver, and kidney did not reveal any $\operatorname{PrP}^{\mathrm{C}}$ expression (data not shown). Tg640 mice developed normally and remained healthy, without any abnormal clinical signs, for $>670 \mathrm{~d}$.

To quantitate total PrP levels in transgenic brains (Fig. 1D) serial twofold dilutions of $\operatorname{tg} 640$ and wild-type brain homogenates in $\mathrm{Prnp}^{\mathrm{o} / \mathrm{o}}$ homogenates were blotted, and the relative expression levels were calculated from calibration curves obtained by direct acquisition of chemiluminescence (Fig. 1E), as described previously (Heppner et al., 2001). The $\operatorname{PrP}^{\mathrm{C}}$ content in $\operatorname{tg} 640$ brains was $\sim 35 \%$ of that found in wild-type mice. Immunoblotting of sciatic nerves of MBP-PrP, Prnp ${ }^{\mathrm{o} / \mathrm{o}}$, and $\operatorname{Prnp}{ }^{+/+}$ mice (Fig. $1 D$ ) revealed expression of $\operatorname{PrP}^{\mathrm{C}}$ in sciatic nerves of MBP-PrP mice. However, the amount of $\mathrm{PrP}^{\mathrm{C}}$ was only $7 \%$ of that found in wild-type mice.

We then analyzed the details of intracerebral $\operatorname{PrP}^{\mathrm{C}}$ distribution in tg640 mice (Fig. $1 F$ ). Western blot analysis of anatomically dissected cortical and subcortical forebrain compartments indicated strong $\operatorname{PrP}^{\mathrm{C}}$ signals in the white matter (subcortex), yet 
$\operatorname{PrP}+1+$
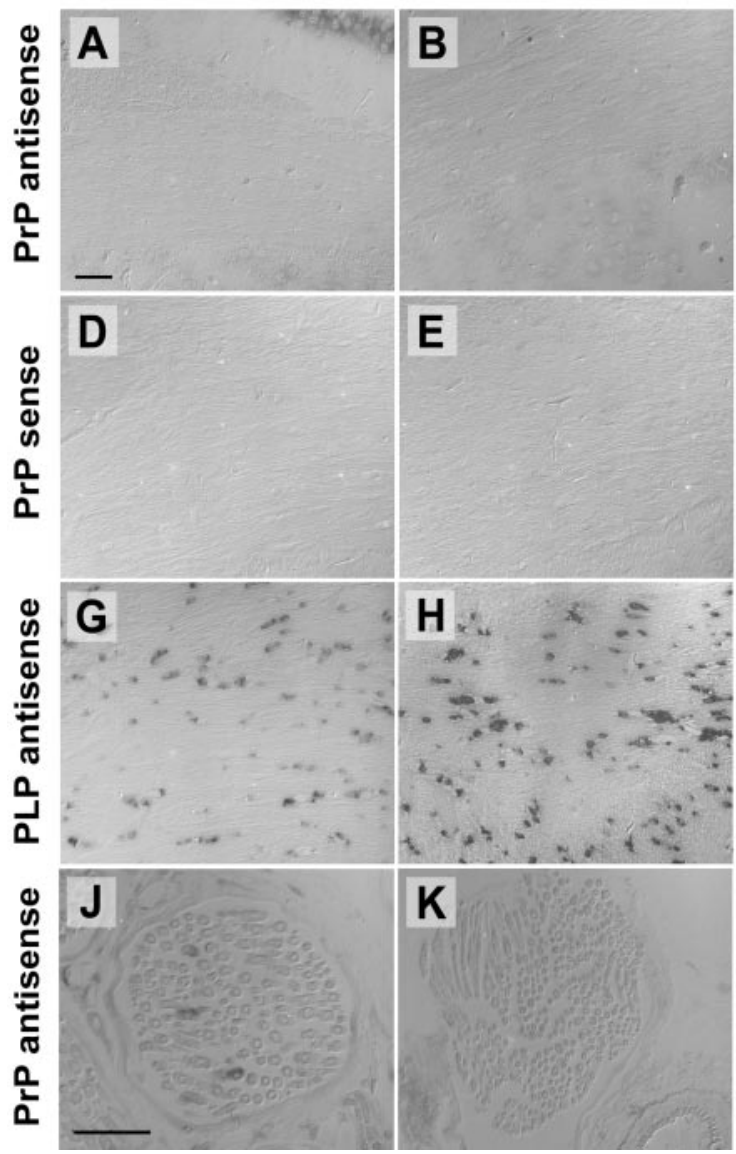

MBP-PrP
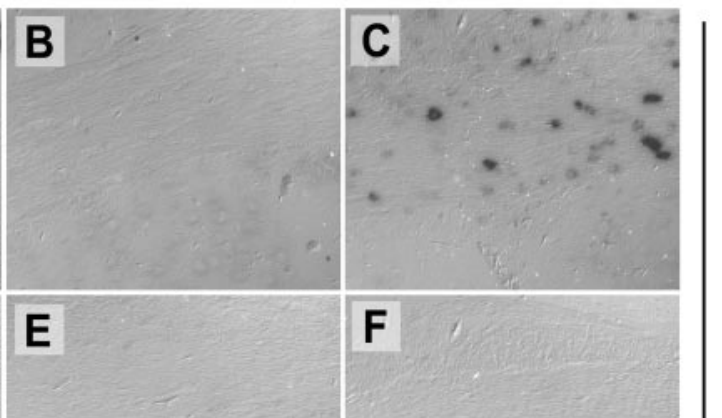

$\mathbf{F}$
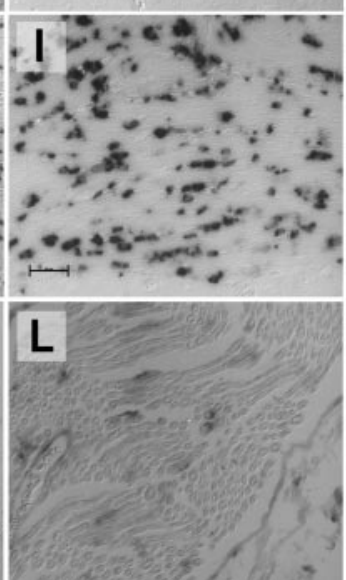

Figure 2. Localization of PrP mRNA in MBP-PrP transgenic mice. In situ hybridization of forebrain sections $(A-l)$ with corpus callosum and of sciatic nerve sections $(J-L)$ of adult Prnp ${ }^{+/+}, P_{r n p}{ }^{0 / 0}$, and MBP-PrP transgenic mice is shown. Expression of PrP mRNA occurs in neurons of wild-type (Prnp ${ }^{+/+}$) forebrains $(A)$ and in Prnp ${ }^{+/+}$Schwann cells $(J)$, whereas Prnp ${ }^{0 / 0}$ brains $(B)$ and nerves $(K)$ lack any signal. In contrast, strong PrP signals are visible in callosal oligodendrocytes $(C)$ and sciatic $S c h w a n n$ cells $(I-L)$ of transgenic mice. $D-F$, Sense probes did not reveal any signals in brains and sciatic nerves. $G-I$, The oligodendrocytespecific PLP antisense probe revealed strong mRNA signals in the forebrains of all genotypes investigated. Scale bars, $50 \mu \mathrm{m}$. did not hybridize (data not shown). Oligodendrocyte-restricted expression of the PrP transgene in brains of $\operatorname{tg} 640$ mice was demonstrated by colocalization of mRNA for Prnp and the oligodendrocytespecific proteolipid protein (PLP) (Fig. $2 G-I)$.

Transmission electron microscopy was used to trace the subcellular distribution of $\operatorname{PrP}^{\mathrm{C}}$ within the white matter of adult mice (Fig. 3A-C). Punctuate distribution of colloidal gold-labeled antibodies to $\operatorname{PrP}^{\mathrm{C}}$ (arrows) was found in axons as well as in surrounding myelin sheaths of wild-type mice (Fig. $3 A$ ), whereas only occasional randomly distributed gold particles were found in $\operatorname{Prnp}^{\mathrm{o} / \mathrm{o}}$ mice. In contrast, tg640 mice displayed the largest number of gold particles within myelinating oligodendrocyte processes (Fig. 3C).

Expression of PrP was also studied by fluorescence microscopy in optic nerve explants from 7- to 8-d-old mice. Strong $\mathrm{PrP}^{\mathrm{C}}$ labeling was observed only in oligodendrocytes derived from $\operatorname{tg} 640$ mice, but not from Prnp ${ }^{+/+}$or Prnp ${ }^{\mathrm{o} / \mathrm{o}}$ mice (Fig. $3 D-F$, top row). Costaining with the early oligodendrocyte marker MAG (Fig. 3D-F, bottom row) confirmed the assignment of signals to oligodendrocytes, as well as the purity of the cultured cells. The majority (but not all) of $\mathrm{MAG}^{+}$-cultured cells also expressed $\mathrm{PrP}^{\mathrm{C}}$. Thus, only more mature cells that had formed membrane sheets between their processes were PrP positive, which correlates with late MBP expression. Ectopic PrP expression did not affect oligodendrocyte density, morphology, or MAG expression. no $\operatorname{PrP}^{\mathrm{C}}$ was detected in the gray matter (cortex). Instead, in wild-type $\left(\operatorname{Prnp}^{+/+}\right)$mice, both compartments contained sizeable levels of $\operatorname{PrP}^{\mathrm{C}}$ (data not shown). MBP-PrP mice displayed a predominant unglycosylated $\operatorname{PrP}^{\mathrm{C}}$ band, whereas wild-type mice show a dominant diglycosylated band, suggesting that posttranslational processing of $\operatorname{PrP}^{\mathrm{C}}$ differs between oligodendrocytes and other CNS cells.

We performed in situ hybridizations on brain and sciatic nerve sections with digoxigenin-labeled riboprobes for $\operatorname{PrP}$ mRNA (Fig. 2). In Prnp ${ }^{+/+}$mice, PrP mRNA was found mainly in neuronal cell bodies but was not detectable in glial cell bodies within fiber tracts, such as in the corpus callosum (Fig. 2A). No Prnp transcripts were detected in the corpus callosum of Prn $p^{\text {o/o }}$ mice (Fig. $2 \mathrm{~B}$ ). In contrast, strong mRNA signals were observed in the corpus callosum and, to a lesser extent, in the cerebral cortex (data not shown) of adult $\operatorname{tg} 640$ brains, indicative of strong PrP expression in oligodendrocytes (Fig. 2C). Control hybridization with digoxigenin-labeled sense transcripts did not yield any signal (Fig. $2 D-F$ ). In situ hybridizations of sciatic nerves yielded PrP signals in both Prnp ${ }^{+/+}$(tga20) and MBP-PrP mice but not in $\operatorname{Prnp}^{\mathrm{o} / \mathrm{o}}$ mice (Fig. $2 J-L$ ). Hybridization signal intensity was less prominent in MBP-PrP mice than in wild-type mice, which is in line with the weaker protein expression. Again, sense probes

\section{Resistance of $\operatorname{tg} 640$ mice to scrapie}

To test whether oligodendrocyte-restricted expression of $\mathrm{PrP}^{\mathrm{C}}$ suffices to render $\operatorname{Prnp}^{\mathrm{o} / \mathrm{o}}$ mice susceptible to scrapie, tg640 mice were challenged with scrapie prions (RML strain, passage 5) intracerebrally, intraperitoneally, or intraocularly. However, challenge of homozygous (intraperitoneally, $n=12$; intracerebrally, $n=10$; intraocularly, $n=7$ ) or hemizygous (intraperitoneally, $n=11$; intracerebrally, $n=10$; intraocularly, $n=6$ ) tg640 mice and, as a control, $\operatorname{Prnp}^{\mathrm{o} / \mathrm{o}}$ mice (intraperitoneally, $n=4$; intracerebrally, $n=5$ ) did not result in clinical signs of scrapie in any of the mice as late as $641 \mathrm{~d}$ postinoculation (dpi). This period of time approaches the natural life span of laboratory mice. Instead, wild-type mice that had been challenged with an inoculum of the same size died of scrapie at $195 \pm 3 \mathrm{~d}$ after intraperitoneal $(n=$ 6), $163 \pm 4 \mathrm{~d}$ after intracerebral $(n=6)$, and $194 \pm 11 \mathrm{~d}$ after intraocular $(n=7)$ inoculation (Table 1$)$. All of these mice developed typical clinical symptoms of scrapie, such as ataxia, paralysis, kyphosis, foot-clasp reflex, and mincing gait. Thus, expression of full-length $\mathrm{PrP}^{\mathrm{C}}$ by oligodendrocytes of $\operatorname{Prnp}^{\mathrm{o} / \mathrm{o}}$ mice does not restore clinical susceptibility to scrapie.

A major hallmark of TSE diseases is brain deposition of $\operatorname{PrP}^{\mathrm{Sc}}$ (McKinley et al., 1983). We assessed formation of $\operatorname{PrP}^{\mathrm{Sc}}$ in scrapie-infected MBP-PrP mice by Western blot analysis of brain 
extracts (Fig. 4A). Terminally scrapie-sick, intracerebrally scrapie-inoculated wild-type mice $\left(\operatorname{Prnp}^{+/+}\right)$showed high levels of $\mathrm{PrP}^{\mathrm{Sc}}$. However, clinically asymptomatic hemizygous tg640 mice killed $210 \mathrm{~d}$ after intracerebral inoculation did not exhibit any detectable $\mathrm{PrP}^{\mathrm{Sc}}$ in their brains. All brains of scrapieinoculated mice surviving until termination of the experiments (641 d postinoculation) were analyzed by histology. This analysis failed to indicate any morphological signs of scrapie, such as spongiosis or gliosis (data not shown).

Next, we investigated whether myelin-derived $\operatorname{PrP}^{\mathrm{C}}$ is required for the accumulation of $\mathrm{PrP}^{\mathrm{Sc}}$ in situ by histoblotting. Mice were killed at the indicated time points and analyzed for the presence of disease-associated $\mathrm{PrP}^{\mathrm{Sc}}$ (Fig. $4 \mathrm{~B}$ ). Large amounts of proteinase $\mathrm{K}$-resistant prion protein were found in infected $\operatorname{Prnp}^{+/+}$mice, whereas MBP-PrP and Prnp ${ }^{\mathrm{o} / \mathrm{o}}$ mice lacked any detectable PK-resistant $\mathrm{PrP}^{\mathrm{Sc}}$. As reported previously (Brandner
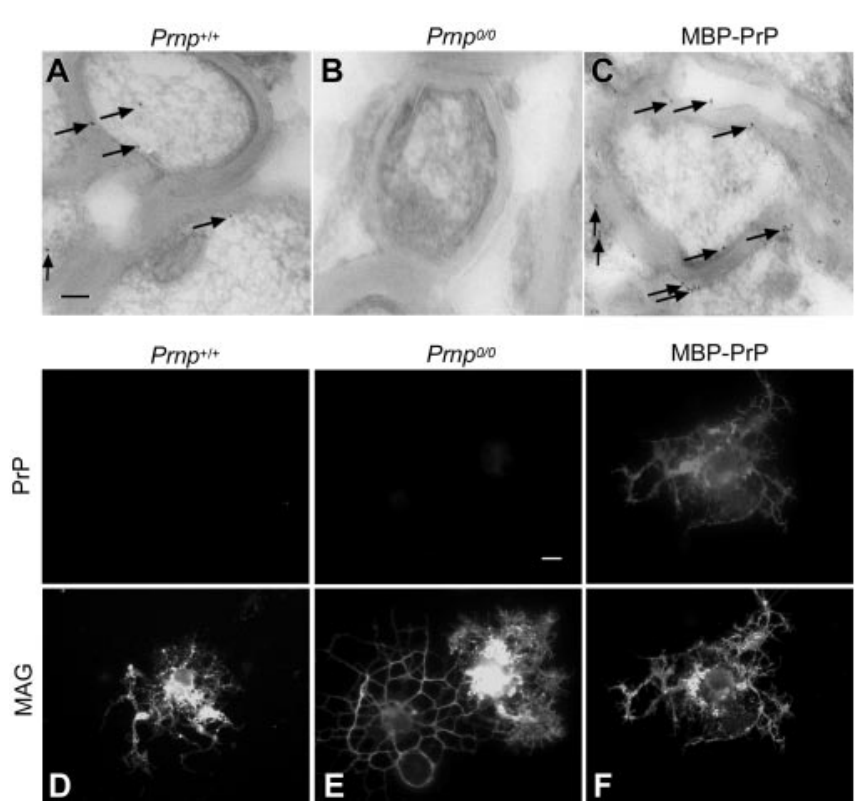

Figure 3. Localization of $\operatorname{PrP}^{C}$ in $M B P-\operatorname{PrP}$ mice. $A-C$, Cellular distribution of $\operatorname{PrP}^{C}$ within the white matter of adult mice revealed by immunoelectron microscopy of gold-labeled anti-PrP antibody. Arrows indicate the location of the black gold particles. MBP-PrP mice display abundant decoration of myelin with gold particles. Scale bar, $5 \mathrm{~nm}$. D-F, Immunofluorescence of primary optic nerve oligodendrocytes cultured from 7- to 8-d-old mice. Top row, expression of PrP is detectable only in transgenic oligodendrocytes $(F)$, whereas the early oligodendrocyte marker MAG is expressed on all oligodendrocytes (bottom row). Scale bar, $5 \mu \mathrm{m}$. et al., 1996a), myelinated structures show faint homogeneous background staining in inoculated $\operatorname{Prnp}^{\mathrm{o} / \mathrm{o}}$ mice. However, these myelinated structures were much less intensive than the $\operatorname{PrP}^{C_{-}}$ containing white-matter tracts in MBP-PrP mice.

To determine whether scrapie infectivity might subclinically propagate in brains or spleens of asymptomatic $\operatorname{tg} 640$ mice, tissue homogenates from animals killed at various time points were injected intracerebrally into indicator tga20 mice (Fischer et al., 1996), which overexpress Prnp under transcriptional control of orthologous regulatory elements (Table 2). Brain homogenates of Prnp ${ }^{+/+}$mice $140 \mathrm{~d}$ after intraperitoneal inoculation or $167 \mathrm{~d}$ after intracerebral inoculation elicited disease in $\operatorname{tga} 20$ mice after $58-71 \mathrm{~d}$. This result was compared with a calibration curve and found to correspond to a prion titer of $\sim 4.9-6.3 \operatorname{logLD} D_{50}$. In contrast, brains of tg640 transgenic mice never induced scrapie after transmission to $\operatorname{tga} 20$ mice. We conclude that $\operatorname{tg} 640$ brains do not replicate prion infectivity despite $\mathrm{PrP}^{\mathrm{C}}$ expression in oligodendrocytes. The detection threshold of the mouse bioassay with $\operatorname{tga} 20$ mice under the conditions used here is $\sim 1.5 \log \mathrm{LD}_{50}$ per gram of tissue.

Low levels of scrapie infectivity were detected in one spleen of a tg640 mouse killed $35 \mathrm{~d}$ after intraperitoneal inoculation, whereas three of four recipient tga20 mice died. This finding is most likely a result of the presence of residual inoculum in this investigated $\operatorname{tg} 640$ mouse. Similar findings have long been known to occur, even after inoculation of $\operatorname{PrP}^{\mathrm{C}}$-deficient mice (Büeler et al., 1993; Sailer et al., 1994). Neuropathological investigations of brains from clinically sick wild-type mice revealed typical signs of scrapie (e.g., spongiform changes and pronounced astrogliosis predominantly in the neocortex and hippocampus; data not shown). In contrast, no typical histopathological signs of scrapie were visible in any of the examined clinically healthy $\operatorname{tg} 640$ mice ( $n=9$; killed at $641 \mathrm{dpi}$; data not shown). These observations virtually exclude the possibility that scrapie prions replicate subclinically in MBP-PrP mice.

\section{Oligodendrocyte-borne $\operatorname{PrP}^{\mathrm{C}}$ does not support oculocerebral prion spread}

Intraocular prion inoculation leads to progressive scrapie pathology along the optic nerve and optic tract to the contralateral superior colliculus and lateral geniculate nucleus, followed by generalized encephalopathy (Fraser, 1982; Brandner et al., 1996b). These results suggest that the infectious agent travels along fiber tracts of the CNS, such as the retinotectal projection.

To determine whether oligodendrocyte-restricted $\operatorname{PrP}^{\mathrm{C}}$ is suf-

Table 1. Resistance to scrapie of MBP-PrP mice

\begin{tabular}{|c|c|c|c|c|c|c|c|c|}
\hline \multirow{3}{*}{$\begin{array}{l}\text { Type of prion challenge } \\
\text { (dose) }\end{array}$} & \multicolumn{8}{|c|}{ Mouse genotypes } \\
\hline & \multicolumn{2}{|c|}{$\mathrm{MBP}-\mathrm{PrP}+/ 0$} & \multicolumn{2}{|c|}{ MBP-PrP ${ }^{+/+}$} & \multicolumn{2}{|l|}{ Prnp $^{+/+}$} & \multicolumn{2}{|l|}{$\operatorname{Prnp}^{0 / 0}$} \\
\hline & Attack rate & Disease latency $^{a}$ & Attack rate & Disease latency $^{a}$ & Attack rate & Disease latency $^{a}$ & Attack rate & Disease latency $^{a}$ \\
\hline $\begin{array}{l}\text { Intraperitoneal } \\
\left(6 \log \mathrm{L}_{50}\right)\end{array}$ & $0 / 11$ & $>641$ & $0 / 12$ & $>467$ & $6 / 6$ & $195 \pm 3$ & $0 / 4$ & $>641$ \\
\hline $\begin{array}{l}\text { Intracerebral } \\
\qquad\left(3 \times 10^{5} L_{50}\right)\end{array}$ & $0 / 10$ & $\begin{array}{l}>641 \\
2 \times>210^{b}\end{array}$ & $0 / 10$ & $\begin{array}{l}>467 \\
1 \times>197^{b}\end{array}$ & $6 / 6$ & $163 \pm 4$ & $0 / 5$ & $\begin{array}{l}>467 \\
1 \times>243^{b}\end{array}$ \\
\hline $\begin{array}{l}\text { Intraocular } \\
\qquad\left(1 \times 10^{5} L_{50}\right)\end{array}$ & $0 / 6$ & $>531^{c}$ & $0 / 7$ & $\begin{array}{l}>410 \\
1 \times>376^{d}\end{array}$ & $7 / 7$ & $194 \pm 11$ & ND & \\
\hline
\end{tabular}

Only control wild-type mice $\left(\right.$ Prnp $\left.{ }^{+/+}\right)$developed scrapie after intraperitoneal, intracerebral, and intraocular prion challenge, whereas mice carrying the MBP-PrP transgene hemizygously or homozygously and Prnp ${ }^{0 / 0}$ mice neve developed clinical signs of scrapie. Average incubation times and SDs were calculated for the groups of mice that developed scrapie. For mice that remained free of disease, the total observation time is reported. All mice were bred to a similar mixed genetic background (C57BL/6 $\times 1295 \mathrm{~V})$. ND, Not determined.

${ }^{a}$ Average \pm SD.

${ }^{b}$ Clinically healthy mice were killed at the time points indicated, and organs were used for infectivity analysis.

'One mouse died $24 \mathrm{hr}$ after inoculation.

${ }^{d}$ Death of one mouse $376 \mathrm{~d}$ after inoculation resulting from abdominal tumor growth. 
ficient for centripetal scrapie spread, prions were inoculated intraocularly, intraperitoneally, and intracerebrally into either tg640 or Prnp ${ }^{\mathrm{o} / \mathrm{o}}$ mice containing a PrP-overexpressing tga20 neurograft (Fig. 5) (Brandner et al., 1996a). Prion injections were performed $\geq 62 \mathrm{~d}$ after transplantation to ensure full differentiation of embryonic tissue into normal neuronal and glial components and its integration into the host brain (Isenmann et al., 1996a).

Tg640 or $\operatorname{Prnp}^{\mathrm{o} / \mathrm{o}}$ mice grafted with tga20 neuroectoderm were killed at $\geq 247 \mathrm{dpi}$. By this time, all intracerebrally infected grafts in both $\operatorname{tg} 640(n=8)$ and $\operatorname{Prnp}^{\mathrm{o} / \mathrm{o}}(n=7)$ hosts had developed severe scrapie encephalopathy, as diagnosed by the presence of typical histopathological features, including spongiosis. Pronounced gliosis typical of scrapie was visualized by immunocytochemistry for GFAP, and synaptic loss was illustrated by coarse granular deposits and patchy staining for synaptophysin. Predominantly synaptic deposits of $\operatorname{PrP}^{\mathrm{Sc}}$ were apparent with the anti-PrP antibody SAF84. In contrast, none of nine tg640 and four $\operatorname{Prnp}^{\mathrm{o} / \mathrm{o}}$ mice that were inoculated intraocularly showed typical histopathological features of scrapie encephalopathy. Identi-

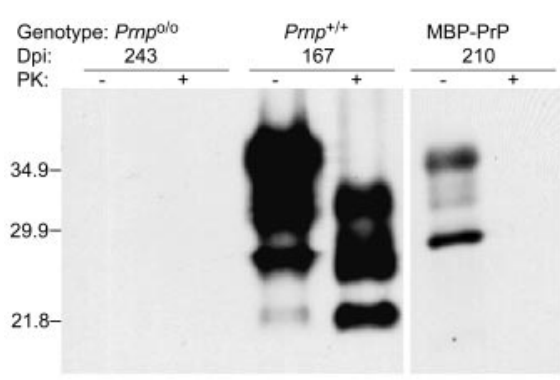

A

Figure 4. Absence of conversion of $\operatorname{PrP}^{C}$ into $\mathrm{PrP}^{\mathrm{Sc}}$ after scrapie challenge of MBP-PrP mice. A, Western blots of homogenized brain material electrophoresed natively $(-)$ or after digestion with proteinase $K(+)$. Large amounts of PK-resistant prion protein $\left(\mathrm{PrP}^{\mathrm{SC}}\right)$ are detectable in brains of wild-type mice $\left(\mathrm{Prnp}^{+/+}\right)$that developed terminal scrapie $167 \mathrm{~d}$ postinoculation. $\mathrm{No}^{\mathrm{PrP}}{ }^{\mathrm{Sc}}$ is visible in $P r n p^{0 / 0}$ or MBP-PrP mice that had been challenged intracerebrally with a high dose of the RML strain. Molecular weight markers are indicated on the left. $B$, Histoblot analysis of PrP ${ }^{\mathrm{Sc}}$ expression. Protease-resistant PrP was detectable only in intracerebrally infected Prnp ${ }^{+/+}$mice. MBP-PrP and Prnp ${ }^{0 / 0}$ mice did not accumulate PrP Sc . As reported previously (Brandner et al., 1996b), myelinated structures show faint homogeneous background staining in inoculated Prnp ${ }^{0 / 0}$ mice. cal results were obtained with five intraperitoneally inoculated tg640 and five $\operatorname{Prnp}^{\mathrm{o} / \mathrm{o}}$ hosts. In two instances, brain grafts of intraocularly inoculated $t g 640$ mice were assayed by transmission of tissue homogenates to groups of four tga20 mice. However, none of the recipient mice developed disease, indicating that the grafts were devoid of prion infectivity. We therefore exclude the possibility that $\operatorname{PrP}^{\mathrm{C}}$, when expressed solely on myelin components, supports prion spread within the CNS.

\section{Discussion}

Spongiosis, neuronal loss, astroglial and microglial activation, and accumulation of $\mathrm{PrP}^{\mathrm{Sc}}$ are the most prominent neuropathological features of TSEs. Although neurons are clearly affected in the disease process, it is still unclear whether other brain cells also play a role. Although it is undisputed that during the course of prion diseases neurons can undergo pathological changes culminating in cell death, it is by no means clear whether neurons are the sole or even the primary target of prions. Previous studies have shown that astrocyte-specific expression of PrP driven by the GFAP promoter is sufficient to mediate susceptibility to scrapie in $\operatorname{Prnp}^{\mathrm{o} / \mathrm{o}}$ mice (Raeber et al., 1997) and, most surprisingly, to produce a pathology similar to that of wild-type mice. Furthermore, it was speculated that oligodendrocytes may also participate in scrapie pathogenesis, because $\mathrm{PrP}^{\mathrm{Sc}}$ accumulated most strongly in the white-matter areas, such as the corpus callosum or the fiber tracts of the striatum, during scrapie disease (Bendheim et al., 1992; Taraboulos et al., 1992). In addition, substantial PrP mRNA expression in the white-matter tracts, as shown previously (Moser et al., 1995), implied that oligodendrocytes might be the primary producers of $\mathrm{PrP}^{\mathrm{Sc}}$ and may be the primary target for prions as well.

Here we describe transgenic mice expressing full-length $\operatorname{PrP}^{\mathrm{C}}$ under the control of the MBP promoter. The MBP expression vector was shown to drive ex-

Table 2. Prion load in brains and spleens of individual $t g 640$ mice

\begin{tabular}{|c|c|c|c|c|c|}
\hline \multirow[b]{2}{*}{$\begin{array}{l}\text { Mouse } \\
\text { genotypes }\end{array}$} & \multirow[b]{2}{*}{$\begin{array}{l}\text { Days after inoculation; } \\
\text { route of infection }\end{array}$} & \multicolumn{2}{|c|}{ Transmission of brain to indicator mice } & \multicolumn{2}{|c|}{ Transmission of spleen to indicator mice } \\
\hline & & $\begin{array}{l}\text { Brain infectivity } \\
\left(\log \mathrm{D}_{50} \text { per gram) }\right.\end{array}$ & $\begin{array}{l}\text { Attack rate } \\
\text { (mean } \pm S D \text { days) }\end{array}$ & $\begin{array}{l}\text { Spleen infectivity } \\
\left(\log \mathrm{D}_{50} \text { per gram) }\right.\end{array}$ & $\begin{array}{l}\text { Attack rate } \\
\text { (mean } \pm S D \text { days) }\end{array}$ \\
\hline \multirow{6}{*}{ MBP-PrP } & \multirow{2}{*}{$35 \mathrm{~d}$; intraperitoneal } & $<1.5$ & $0 / 4$ & $<1.5$ & $0 / 4$ \\
\hline & & $<1.5$ & $0 / 4$ & $<1.5$ & $3 / 4(99,148,150)^{a}$ \\
\hline & \multirow[t]{2}{*}{$140 \mathrm{~d}$; intraperitoneal } & $<1.5$ & $0 / 4$ & $<1.5$ & $0 / 4$ \\
\hline & & $<1.5$ & $0 / 4$ & $<1.5$ & $0 / 4$ \\
\hline & \multirow{2}{*}{$210 \mathrm{~d}$; intracerebral } & $<1.5$ & $0 / 4$ & $<1.5$ & $0 / 4$ \\
\hline & & $<1.5$ & $0 / 3$ & $<1.5$ & $0 / 4$ \\
\hline \multirow[t]{6}{*}{ Prnp ${ }^{+/+}$} & \multirow[t]{2}{*}{$35 \mathrm{~d}$; intraperitoneal } & $<1.5$ & $0 / 4$ & 5.0 & $4 / 4(73 \pm 5)$ \\
\hline & & $<1.5$ & $0 / 4$ & 5.1 & $4 / 4(72 \pm 4)$ \\
\hline & \multirow[t]{2}{*}{$140 \mathrm{~d}$; intraperitoneal } & 5.3 & $4 / 4(68 \pm 6)$ & 4.0 & $3 / 3(84 \pm 4)$ \\
\hline & & 4.9 & $4 / 4(74 \pm 7)$ & 5.1 & $4 / 4(72 \pm 8)$ \\
\hline & \multirow[t]{2}{*}{167 d; intracerebral } & 6.3 & $4 / 4(58 \pm 6)$ & 5.1 & $4 / 4(72 \pm 5)$ \\
\hline & & 6.1 & $4 / 4(60 \pm 7)$ & 5.3 & $4 / 4(70 \pm 2)$ \\
\hline \multirow[t]{2}{*}{ Prnp ${ }^{0 / 0}$} & \multirow[t]{2}{*}{$42 \mathrm{~d}$; intraperitoneal } & $<1.5$ & $0 / 4$ & $<1.5$ & $0 / 4$ \\
\hline & & $<1.5$ & $0 / 4$ & $<1.5$ & $1 / 4(99)$ \\
\hline
\end{tabular}

Wild-type $\left(P r n p^{+/+}\right)$and tg640 mice homozygous for the MBP-PrP transgenic cluster were inoculated intraperitoneally and intracerebrally and killed for analysis at the time points indicated.

${ }^{a}$ Prion disease in three of four tga 20 indicator mice that had received spleen extracts from a 35 dpi-challenged tg 640 mouse is most likely a result of prions persisting from the inoculum. 
pression of the smallest isotype of myelin basic protein and cure the hypomyelinating mouse model shiverer (Kimura et al., 1989). Only one of nine transgenic lines expressed sustained levels of $\mathrm{PrP}^{\mathrm{C}}$. Inherent toxicity of the transgene is unlikely, because the incidence of transgene-positive founder mice was normal and line $\operatorname{tg} 640$ exhibited undistorted Mendelian transmission of the MBP-PrP transgene. The relative inefficiency of expression may be specific to the MBP-PrP minigene with a coding exon of $1.3 \mathrm{~kb}$ flanked by two small artificial introns. In tg640 mice, full-length $\mathrm{PrP}^{\mathrm{C}}$ was found exclusively on oligodendrocytes and on Schwann cells but was absent from other tissues and cell types. Although the constitutive level of $\operatorname{PrP}^{\mathrm{C}}$ in the total brains of transgenic mice was only $\sim 30-35 \%$ of that observed in the normal mouse brain, $\mathrm{PrP}^{\mathrm{C}}$ protein was clearly overexpressed on transgenic oligodendrocytes compared with wild-type oligodendrocytes.

There was no evidence for $\operatorname{PrP}^{\mathrm{C}}$ expression in either neurons or astrocytes. If any expression occurred, it would be under the detection limit of the methods used. Perhaps the strongest argument for the strict specificity of expression in oligodendrocytes is that we could not detect replication of prions in transgenic mice, whereas we know from studies published previously that even very low levels of expression in astrocytes or neurons would restore cerebral prion replication (Büeler et al., 1994; Race et al., 1995; Raeber et al., 1997). Inoculation of $\operatorname{tg} 640$ mice with scrapie prions by different routes did not induce clinical disease or cerebral $\mathrm{PrP}^{\mathrm{Sc}}$ deposition. This was unexpected in view of the proposed role of oligodendrocytes during disease, as described above.

The fact that $\operatorname{PrP}^{\mathrm{C}}$ expression was genuinely restricted to oligodendrocytes allowed us to ask questions related to the spread of prions within the CNS. Intraocular inoculation into $\operatorname{Prnp}^{\mathrm{o} / \mathrm{o}}$ mice carrying $\mathrm{PrP}^{\mathrm{C}}$-overexpressing grafts did not provoke scrapie in grafts, supporting the conjecture that lack of $\mathrm{PrP}^{\mathrm{C}}$ on cells belonging to the visual pathway prevents prion spread within the CNS (Brandner et al., 1996b). However, it is unclear which mechanisms, be they axonal or nonaxonal, may be involved. Nonneuronal cells, including oligodendrocytes in the CNS and Schwann cells, may play a supportive or obligate role. Within the framework of the prion-only hypothesis, one might hypothesize a "domino" mechanism, by which incoming $\mathrm{PrP}^{\mathrm{Sc}}$ converts resident $\operatorname{PrP}^{\mathrm{C}}$ on the axolemmal or myelin surface, thereby spatially propagating the infection (Aguzzi and Weissmann, 1997). Indeed, one study showed that the velocity of neuronal prion spread is extremely slow (Kimberlin et al., 1983) and may not follow the canonical mechanisms of fast axonal transport. Additional findings support nonaxonal transport mechanisms that result in periaxonal deposition of $\mathrm{PrP}^{\mathrm{Sc}}$ (Hainfellner and Budka, 1999; Glatzel and Aguzzi, 2000).

In a neurograft paradigm, we find that oligodendrocyte-borne $\operatorname{PrP}^{\mathrm{C}}$ does not support transfer of prion infectivity from the eye to intracerebral compartments. Could the negative outcome of the grafting experiment be caused by technical problems of grafting or of intraocular inoculation? This is unlikely, because tga20 neurografts are easily infectible via the optic route when implanted into Prnp ${ }^{+/ o}$ hosts, but not when grafted into Prnp ${ }^{\text {o/o }}$ hosts (Brandner et al., 1996b).

Our findings on the ineffective spread of prions along the visual pathway of $\operatorname{tg} 640$ mice do not favor the nonaxonal theory. The hypothesis that spread of prions occurs axonally rests mainly on the demonstration of progressive spongiform changes along the retinal pathway after intraocular infection (Fraser, 1982). Within these experiments, the spread of scrapie pathology was observed first in the contralateral superior colliculus followed by the lateral geniculate nucleus and visual cortex.

The negative outcome of all prion-related tests prompted us to verify that MBP-PrP mice express intact $\mathrm{PrP}^{\mathrm{C}}$ on myelinating cells. Northern and Western blot analyses, as well as in situ hybridization, confirmed correct transcription of the transgene and translation into PrP-immunoreactive protein with the expected molecular characteristics. Because prion replication may be compromised even by immunochemically silent point mutations, we sequenced the integrated transgene from PCR-amplified genomic DNA. Again, no deviations from the expected sequence were identified. Finally, we verified MBP-PrP transcripts by sequencing reverse transcription-PCR amplification products from brain homogenates. The results of the latter assay rule out RNA editing, which might lead to expression of mutated proteins despite correct genomic sequences.

We still do not know how prions propagate within the brain. The current study excludes any oligodendrocytic contribution to prion pathogenesis by a $\operatorname{PrP}^{\mathrm{C}}$-dependent cell-autonomous mechanism. It is still possible, however, that oligodendrocytic $\mathrm{PrP}^{\mathrm{C}}$ modulates the speed of prion neuroinvasion in a non-cellautonomous manner, perhaps by transcellular "painting" of glycosylphosphatidylinositol-linked proteins to adjacent axolem- 
mal surfaces. Conversely, other experiments suggest that $\operatorname{PrP}^{\mathrm{Sc}}$ of neuronal origin is unlikely to disturb oligodendrocyte physiology to a clinically significant degree (Mallucci et al., 2003). The mouse model described here will make it possible to address this and related questions in a direct way.

\section{References}

Aguzzi A, Weissmann C (1997) Prion research: the next frontiers. Nature 389:795-798.

Aguzzi A, Montrasio F, Kaeser PS (2001) Prions: health scare and biological challenge. Nat Rev Mol Cell Biol 2:118-126.

Archer F, Bachelin C, Andreoletti O, Besnard N, Perrot G, Langevin C, Le Dur A, Vilette D, Baron-Van Evercooren A, Vilotte JL, Laude H (2004) Cultured peripheral neuroglial cells are highly permissive to sheep prion infection. J Virol 78:482-490.

Basler K, Oesch B, Scott M, Westaway D, Walchli M, Groth DF, McKinley MP, Prusiner SB, Weissmann C (1986) Scrapie and cellular PrP isoforms are encoded by the same chromosomal gene. Cell 46:417-428.

Bendheim PE, Brown HR, Rudelli RD, Scala LJ, Goller NL, Wen GY, Kascsak RJ, Cashman NR, Bolton DC (1992) Nearly ubiquitous tissue distribution of the scrapie agent precursor protein. Neurology 42:149-156.

Brandner S, Isenmann S, Raeber A, Fischer M, Sailer A, Kobayashi Y, Marino S, Weissmann C, Aguzzi A (1996a) Normal host prion protein necessary for scrapie-induced neurotoxicity. Nature 379:339-343.

Brandner S, Raeber A, Sailer A, Blattler T, Fischer M, Weissmann C, Aguzzi A (1996b) Normal host prion protein (PrPC) is required for scrapie spread within the central nervous system. Proc Natl Acad Sci USA 93:13148-13151.

Büeler H, Raeber A, Sailer A, Fischer M, Aguzzi A, Weissmann C (1994) High prion and PrPSc levels but delayed onset of disease in scrapieinoculated mice heterozygous for a disrupted PrP gene. Mol Med $1: 19-30$.

Büeler HR, Fischer M, Lang Y, Bluethmann H, Lipp HP, DeArmond SJ, Prusiner SB, Aguet M, Weissmann C (1992) Normal development and behaviour of mice lacking the neuronal cell-surface PrP protein. Nature 356:577-582.

Büeler HR, Aguzzi A, Sailer A, Greiner RA, Autenried P, Aguet M, Weissmann C (1993) Mice devoid of PrP are resistant to scrapie. Cell 73:1339-1347.

Duffy P, Wolf J, Collins G, DeVoe AG, Streeten B, Cowen D (1974) Possible person-to-person transmission of Creutzfeldt-Jakob disease. N Engl J Med 290:692-693.

El Hachimi KH, Chaunu MP, Brown P, Foncin JF (1998) Modifications of oligodendroglial cells in spongiform encephalopathies. Exp Neurol 154:23-30.

Fischer M, Rülicke T, Raeber A, Sailer A, Moser M, Oesch B, Brandner S, Aguzzi A, Weissmann C (1996) Prion protein (PrP) with aminoproximal deletions restoring susceptibility of PrP knockout mice to scrapie. EMBO J 15:1255-1264.

Flechsig E, Shmerling D, Hegyi I, Raeber AJ, Fischer M, Cozzio A, von Mering C, Aguzzi A, Weissmann C (2000) Prion protein devoid of the octapeptide repeat region restores susceptibility to scrapie in PrP knockout mice. Neuron 27:399-408.

Follet J, Lemaire-Vieille C, Blanquet-Grossard F, Podevin-Dimster V, Lehmann S, Chauvin JP, Decavel JP, Varea R, Grassi J, Fontes M, Cesbron JY (2002) PrP expression and replication by Schwann cells: implications in prion spreading. J Virol 76:2434-2439.

Fraser H (1982) Neuronal spread of scrapie agent and targeting of lesions within the retino-tectal pathway. Nature 295:149-150.

Glatzel M, Aguzzi A (2000) $\operatorname{PrP}(\mathrm{C})$ expression in the peripheral nervous system is a determinant of prion neuroinvasion. J Gen Virol 81:2813-2821.
Hainfellner JA, Budka H (1999) Disease associated prion protein may deposit in the peripheral nervous system in human transmissible spongiform encephalopathies. Acta Neuropathol (Berl) 98:458-460.

Heppner FL, Musahl C, Arrighi I, Klein MA, Rulicke T, Oesch B, Zinkernagel RM, Kalinke U, Aguzzi A (2001) Prevention of scrapie pathogenesis by transgenic expression of anti-prion protein antibodies. Science 294:178-182.

Isenmann S, Brandner S, Sure U, Aguzzi A (1996a) Telencephalic transplants in mice: characterization of growth and differentiation patterns. Neuropathol Appl Neurobiol 22:108-117.

Isenmann S, Brandner S, Kuhne G, Boner J, Aguzzi A (1996b) Comparative in vivo and pathological analysis of the blood-brain barrier in mouse telencephalic transplants. Neuropathol Appl Neurobiol 22:118-128.

Katsuki M, Sato M, Kimura M, Yokoyama M, Kobayashi K, Nomura T (1988) Conversion of normal behavior to shiverer by myelin basic protein antisense cDNA in transgenic mice. Science 241:593-595.

Kimberlin RH, Hall SM, Walker CA (1983) Pathogenesis of mouse scrapie Evidence for direct neural spread of infection to the CNS after injection of sciatic nerve. J Neurol Sci 61:315-325.

Kimura M, Sato M, Akatsuka A, Nozawa-Kimura S, Takahashi R, Yokoyama M, Nomura T, Katsuki M (1989) Restoration of myelin formation by a single type of myelin basic protein in transgenic shiverer mice. Proc Natl Acad Sci USA 86:5661-5665.

Mallucci G, Dickinson A, Linehan J, Klohn PC, Brandner S, Collinge J (2003) Depleting neuronal $\mathrm{PrP}$ in prion infection prevents disease and reverses spongiosis. Science 302:871-874.

McKinley MP, Bolton DC, Prusiner SB (1983) A protease-resistant protein is a structural component of the scrapie prion. Cell 35:57-62.

Moser M, Colello RJ, Pott U, Oesch B (1995) Developmental expression of the prion protein gene in glial cells. Neuron 14:509-517.

Prinz M, Montrasio F, Klein MA, Schwarz P, Priller J, Odermatt B, Pfeffer K, Aguzzi A (2002) Lymph nodal prion replication and neuroinvasion in mice devoid of follicular dendritic cells. Proc Natl Acad Sci USA 99:919-924.

Prusiner SB, Cochran SP, Groth DF, Downey DE, Bowman KA, Martinez HM (1982) Measurement of the scrapie agent using an incubation time interval assay. Ann Neurol 11:353-358.

Race RE, Priola SA, Bessen RA, Ernst D, Dockter J, Rall GF, Mucke L, Chesebro B, Oldstone MB (1995) Neuron-specific expression of a hamster prion protein minigene in transgenic mice induces susceptibility to hamster scrapie agent. Neuron 15:1183-1191.

Raeber AJ, Race RE, Brandner S, Priola SA, Sailer A, Bessen RA, Mucke L, Manson J, Aguzzi A, Oldstone MB, Weissmann C, Chesebro B (1997) Astrocyte-specific expression of hamster prion protein $(\mathrm{PrP})$ renders $\operatorname{PrP}$ knockout mice susceptible to hamster scrapie. EMBO J 16:6057-6065.

Sailer A, Büeler H, Fischer M, Aguzzi A, Weissmann C (1994) No propagation of prions in mice devoid of PrP. Cell 77:967-968.

Schwab ME, Caroni P (1988) Oligodendrocytes and CNS myelin are nonpermissive substrates for neurite growth and fibroblast spreading in vitro. J Neurosci 8:2381-2393.

Scott JR, Foster JD, Fraser H (1993) Conjunctival instillation of scrapie in mice can produce disease. Vet Microbiol 34:305-309.

Shmerling D, Hegyi I, Fischer M, Blattler T, Brandner S, Gotz J, Rulicke T, Flechsig E, Cozzio A, von Mering C, Hangartner C, Aguzzi A, Weissmann C (1998) Expression of amino-terminally truncated PrP in the mouse leading to ataxia and specific cerebellar lesions. Cell 93:203-214.

Taraboulos A, Jendroska K, Serban D, Yang SL, DeArmond SJ, Prusiner SB (1992) Regional mapping of prion proteins in brain. Proc Natl Acad Sci USA 89:7620-7624.

Tokuyasu KT (1976) Membranes as observed in frozen sections. J Ultrastruct Res 55:281-287. 